\title{
PENGEMBANGAN MULTIMEDIA INTERAKTIF KOMPETENSI DASAR MENGOPERASIKAN SOFTWARE BASIS DATA UNTUK SMK NEGERI 1 SEYEGAN
}

\author{
Wirawan Yogiyatno \\ Program Studi Pendidikan Teknologi dan Kejuruan PPs UNY \\ wirawany@gmail.com \\ Herminarto Sofyan \\ Universitas Negeri Yogyakarta \\ hermin@uny.ac.id
}

\begin{abstract}
Abstrak
Penelitian ini bertujuan untuk (1) menghasilkan produk multimedia interaktif pada Kompetensi Dasar Mengoperasikan Software Basis Data, (2) mengetahui kelayakan produk multimedia interaktif tersebut, (3) mengetahui keefektifan pembelajaran dengan multimedia interaktifyang dikembangkan dibandingkan dengan pembelajaran tanpa multimedia interaktif tersebut. Penelitian ini merupakan penelitian dan pengembangan berdasarkan model Alessi \& Trollip yang pelaksanaan uji coba keefektifannya menggunakan quasi eksperimen. Data yang dikumpulkan meliputi kualitas produk pengembangan dan hasil belajar. Analisis data dilakukan dengan statistik deskriptif, inferensial menggunakan uji t, serta ukuran pengaruh. Hasil penelitian menunjukkan bahwa: (1) produk yang dihasilkan adalah multimedia interaktif berupa simulasi software basis data, (2) hasil tes alfa dan tes beta menunjukkan bahwa produk yang dikembangkan mempunyai kualitas baik sehingga layak untuk uji coba, (3) pembelajaran dengan multimedia interaktif yang dikembangkan lebih efektif dibandingkan dengan pembelajaran tanpa multimedia interaktif tersebut.
\end{abstract}

Kata kunci: multimedia interaktif, simulasi, basis data, hasil belajar

\section{DEVELOPING OPERATING DATABASE SOFTWARE BASIC COMPETENCY INTERACTIVE MULTIMEDIA FOR SMK NEGERI 1 SEYEGAN}

\begin{abstract}
This study aims to (1) produce an interactive multimedia on Operating Database Software Basic Competency, (2) find out the quality of the product, (3) find out the effectiveness of learning using the developed product compared to learning without using it. This study was a research and development study based on Alessi \& Trollip model in which the effectiveness tryout employed a quasi-experiment. The collected data consisted of those on the quality of the developed product and students'learning outcome. The data were analyzed by means of the descriptive statistics, inferential statistics using $t$-test, and effect size. The results of the study shows that: (1) the developed product is an interactive multimedia which is a database software simulation, (2) the results of alpha and beta tests show that the developed product has a good quality so that it is appropriate for the tryout, (3) learning using the developed product is more effective than that without using it.
\end{abstract}

Keywords: interactive multimedia, simulation, database, learning outcome 


\section{PENDAHULUAN}

Sekolah menengah kejuruan (SMK) merupakan salah satu jalur pendidikan dalam sistem pendidikan nasional. Salah satu tujuan SMK adalah menyiapkan peserta didik agar dapat bekerja, baik dengan mengembangkan usaha secara mandiri atau memenuhi lowongan pekerjaan yang ada di dunia usaha dan dunia industri.

Untuk dapat memenangkan persaingan dalam mendirikan usaha secara mandiri atau mengisi lowongan pekerjaan di dunia usaha dan dunia industri, lulusan SMK tidak hanya dapat mengandalkan kompetensi kejuruan produktif semata. Beberapa kompetensi kelompok non produktif juga perlu dikuasai untuk membantu memenangkan persaingan di dunia wirausaha dan juga dunia industri serta dunia usaha. Salah satu kompetensi kelompok non produktif tersebut adalah kemampuan memanfaatkan teknologi informasi dan komunikasi.

Bagi siswa SMK, penguasaan teknologi informasi dan komunikasi dapat menunjang dan memudahkan pekerjaan di bidang keahliannya kelak. Baik bekerja di dunia usaha dan dunia industri atau berwirausaha, kemampuan dasar di bidang teknologi informasi dan komunikasi akan sangat membantu mereka. Pemanfaatan dasar teknologi informasi dan komunikasi sebagaimana yang disebutkan sebelumnya dipelajari oleh seluruh siswa SMK dari kompetensi keahlian apa pun. Teknologi informasi dan komunikasi yang dipelajari secara umum oleh seluruh siswa SMK ini terdapat pada mata pelajaran Keterampilan Komputer dan Pengelolaan Informasi.

Sesuai dengan Peraturan Menteri Pendidikan Nasional Nomor 22 Tahun 2006 tentang Standar Isi, mata pelajaran Keterampilan Komputer dan Pengelolaan Informasi bertujuan agar peserta didik mempunyai kemampuan untuk menggunakan teknologi komputer dalam kehidupan sehari-hari serta mengaplikasikan komputer sesuai dengan standar kompetensi kerja.

Menurut Peraturan Menteri Pendidikan Nasional Nomor 22 Tahun 2006, standar kompetensi yang terdapat pada mata pelajaran Keterampilan Komputer dan Pengelolaan Informasi adalah mengoperasikan personal computer stand alone, mengoperasikan sistem operasi software, mengolah data aplikasi, mengopera- sikan personal computer dalam jaringan, dan mengoperasikan web design. Kelima standar kompetensi tersebut masih terbagi lagi menjadi 16 kompetensi dasar.

Salah satu kompetensi dasar yang terdapat dalam standar kompetensi mengoperasikan sistem operasi software adalah kompetensi dasar Mengoperasikan Software Basis Data. Secara garis besar, materi pembelajaran Mengoperasikan Software Basis Data terdiri atas struktur basis data, menu-menu software basis data, pembuatan file basis data, penyimpanan file basis data, pengolahan file basis data, penggunaan software basis data untuk memasukkan data sesuai kebutuhan ke table tunggal, pensettingan field basis data menjadi sebuah primary key, perintah editing sederhana untuk menambah, mengubah, menghapus record sesuai kebutuhan, form antarmuka basis data, dan pencetakan file basis data.

Berdasarkan pengalaman selama tiga tahun mengampu mata pelajaran Keterampilan Komputer dan Pengelolaan Informasi di SMK Negeri 1 Seyegan, hasil belajar siswa pada kompetensi dasar Mengoperasikan Software Basis Data adalah paling rendah dibandingkan hasil belajar pada kompetensi dasar lain pada mata pelajaran Keterampilan Komputer dan Pengelolaan Informasi.

Nilai ulangan kenaikan kelas XI mata pelajaran KKPI untuk kompetensi dasar mengoperasikan software basis data dan mengolah data aplikasi dari semua kelas di SMK Negeri 1 Seyegan pada tahun 2012 ditunjukkan pada tabel-tabel berikut:

Tabel 1. Persentase Nilai Ulangan Kenaikan Kelas

\begin{tabular}{lcc}
\hline Kelas & $\geq \mathbf{K K M}$ & $<\mathbf{K K M}$ \\
\hline XI TKR 1 & $70,6 \%$ & $29,4 \%$ \\
XI TKR 2 & $28,1 \%$ & $71,9 \%$ \\
XI TKR 3 & $50 \%$ & $50 \%$ \\
XI TKBB & $3,2 \%$ & $96,8 \%$ \\
XI TGB 1 & $12,12 \%$ & $87,88 \%$ \\
XI TGB 2 & $26,5 \%$ & $73,5 \%$ \\
XI TFL 1 & $50 \%$ & $50 \%$ \\
XI TFL 2 & $74,3 \%$ & $25,7 \%$ \\
XI TO 1 & $25,7 \%$ & $74,3 \%$ \\
XI TO 2 & $48,6 \%$ & $51,4 \%$ \\
XI TO 3 & $48,6 \%$ & $51,4 \%$ \\
\hline
\end{tabular}


Dengan membandingkan nilai ulangan kenaikan kelas pada data di atas terhadap nilai kriteria ketuntasan minimal mata pelajaran KKPI yang telah ditetapkan SMK Negeri 1 Seyegan sebesar 75 , didapatkan data bahwa terdapat 223 siswa dari 374 siswa $(59,63 \%)$ yang nilai ulangan kenaikan kelasnya di bawah nilai kriteria ketuntasan minimal. Dari data tersebut tampaklah jelas bahwa hasil belajar kebanyakan siswa masih berada di bawah nilai kriteria ketuntasan minimal. Hal ini menunjukkan bahwa proses pembelajaran kompetensi dasar Mengoperasikan Software Basis Data perlu ditinjau lebih dalam agar hasil belajar mayoritas siswa dapat mencapai nilai setara atau lebih besar dari nilai kriteria ketuntasan minimal.

Berdasarkan pengalaman mengampu mata pelajaran KKPI selama tiga tahun, pembelajaran kompetensi dasar Mengoperasikan Software Basis Data selama ini dilangsungkan dengan metode ceramah dan demonstrasi. Frekuensi guru dalam mendemonstrasikan kurang; seringkali hanya dilakukan satu kali demonstrasi. Media pembelajaran yang selama ini digunakan berupa media konvensional yang berupa: (1) modul; (2) papan tulis; (3) gambar bergerak proyeksi.

Pembelajaran yang diterapkan dengan metode dan media seperti tersebut di atas masih menunjukkan bahwa proses pembelajaran berlangsung klasikal dan menitikberatkan pada proses menghafal daripada memahami konsep. Akibatnya, tingkat pemahaman siswa terhadap materi pembelajaran rendah. Selain itu, pembelajaran dengan metode dan media seperti tersebut di atas tidak memberi kesempatan yang luas bagi siswa untuk belajar secara mandiri.

Dari wawancara informal dengan siswa, diketahui juga bahwa pertanyaan dan umpan balik yang muncul saat pengoperasian software yang salah yang disajikan dalam bahasa Inggris tidak begitu dapat dipahami oleh siswa. Terlebih lagi, software basis data merupakan software yang lebih sering mengeluarkan umpan balik karena tuntutan presisi pengoperasiannya.

Dari hasil observasi di atas, hal yang perlu ditinjau ulang pada pembelajaran kompetensi dasar Mengoperasikan Software Basis Data di SMK Negeri 1 Seyegan adalah penerapan metode pembelajaran yang tepat sesuai karakteristik kompetensi dasar tersebut serta yang lebih memungkinkan siswa agar mereka mempunyai kesempatan luas untuk belajar secara mandiri. Metode pembelajaran yang digunakan pada kompetensi dasar ini harus sesuai dengan karakteristik materinya yang menuntut pemahaman konsep dan penerapan konsep tersebut pada perangkat lunak nyata. Selain itu, perlu dipikirkan cara untuk menyajikan umpan balik pesan kesalahan atau pertanyaan dalam bahasa Indonesia sehingga siswa merasa nyaman dan lebih mudah memahami pesan tersebut.

Untuk memenuhi kebutuhan pembelajaran yang sesuai dengan karakteristik kompetensi dasar Mengoperasikan Software basis data dan memberi kesempatan yang luas kepada siswa untuk belajar mandiri serta memenuhi harapan antarmuka yang lebih dapat dipahami dalam bahasa Indonesia, pembelajaran dengan multimedia interaktif dalam bentuk simulasi pelatihan software merupakan alternatif yang sesuai. Secara umum, multimedia interaktif merupakan gabungan yang telah menyatu dari elemen teks, grafis, suara, animasi, dan video yang dimanipulasi secara digital dan mampu merespon input pengguna. Sedangkan, simulasi pelatihan software merupakan program yang mensimulasikan sebuah perangkat lunak di mana pengguna mempelajarinya melalui interaksi.

Simulasi pelatihan software dengan multimedia interaktif dalam pembelajaran kompetensi dasar Mengoperasikan Software Basis Data ini diperkirakan mampu membantu meningkatkan hasil belajar siswa dengan pertimbangan: (1) simulasi memberikan pengalaman sebagaimana pengalaman mengoperasikan software basis data nyata namun bisa meminimalkan resiko perubahan sistem komputer akibat pengoperasian software basis data yang tidak tepat, (2) simulasi mampu memberikan arahan petunjuk pengoperasian software basis data dengan umpan balik per langkah pengoperasian, (3) simulasi mampu menampilkan umpan balik pengoperasian dalam bahasa Indonesia yang lebih dipahami siswa alih-alih menampilkan umpan balik pengoperasian dalam bahasa asing yang kurang dipahami siswa sebagaimana software basis data sebenarnya, (4) 
simulasi memungkinkan pembelajaran mandiri seperti pengulangan materi tertentu sesuai keinginan siswa di mana hal itu sulit dilakukan jika menggunakan software basis data sebenarnya.

Dengan karakteristik simulasi di atas, diharapkan siswa lebih memahami konsep pengoperasian software basis data. Jika siswa mampu memahami konsep pengoperasian software basis data, diharapkan hasil belajarnya pun meningkat minimal setara nilai kriteria ketuntasan minimal. Walaupun demikian, multimedia interaktif untuk pembelajaran kompetensi dasar Mengoperasikan Software Basis Data belum tersedia di SMK Negeri 1 Seyegan. Memang telah tersedia produk multimedia pembelajaran Microsoft Access 2007 yang tersedia di pasaran, namun produk tersebut diperuntukkan untuk umum, bukan khusus untuk siswa SMK. Dikarenakan untuk umum, materi yang ada pada produk tersebut terlalu luas dan tidak sesuai dengan indikator-indikator pada kompetensi dasar Mengoperasikan Software Basis Data yang dipelajari di SMK. Dengan demikian perlu dikembangkan sebuah perangkat lunak multimedia interaktif yang sesuai dengan kompetensi dasar Mengoperasikan Software Basis Data. Setelah perangkat lunak tersebut dikembangkan, kelayakan dan keefektifan perangkat lunak multimedia interaktif ini perlu diketahui. Oleh karena itu, pengembangan, kelayakan, dan keefektifan perangkat lunak multimedia interaktif ini perlu untuk diteliti.

\section{Media pembelajaran}

Saat ini, kegiatan guru dan siswa lebih banyak disebut dengan pembelajaran. Istilah pembelajaran telah menggantikan istilah seperti pengajaran yang dianggap lebih berpusat pada guru. Pembelajaran adalah suatu upaya sistematis dan sistemik yang sengaja diprogramkan untuk memfasilitasi belajar siswa dan meningkatkan kualitas belajar. Hal ini sejalan dengan pernyataan (Gagne, Briggs \& Wager dalam Winataputra, 2008:19).

Heinich et.al. (1996:8) menyatakan bahwa pembelajaran merupakan pengaturan informasi dan lingkungan untuk memfasilitasi belajar. Kata lingkungan di sini tidak terbatas hanya pada konteks tempat di mana belajar berlangsung. Lingkungan yang dimaksudkan di sini bisa berupa model, metode, strategi, media, dan atau sarana yang dibutuhkan untuk memfasilitasi belajar siswa.

Salah satu komponen yang diatur agar belajar terjadi adalah media. Media merupakan kata dari bahasa Latin dan digunakan untuk mendeskripsikan cara untuk mengekspresikan pesan-pesan dan informasi (Usha dalam Sidhu, 2010:24). Suatu media bisa disebut sebagai media pembelajaran jika media tersebut menyediakan pesan dan informasi untuk keperluan pembelajaran (Smaldino, 2004:9). Dengan demikian, media pembelajaran adalah penyampai materi pembelajaran dari sumber belajar kepada pembelajar. Bentuk dari media pembelajaran mengacu kepada bentuk media secara umum, misalnya bahan-bahan tercetak, diagram, rekaman audio, video, televisi, dan program perangkat lunak komputer.

\section{Multimedia interaktif}

Multimedia merupakan gabungan yang telah menyatu dari elemen-elemen teks, fotografi, seni grafis, suara, animasi, dan video yang dimanipulasi secara digital (Ivers dan Barron, 2002:2; Vaughan, 2011:1). Kriteria pemanipulasian secara digital mempunyai kedudukan penting dari definisi ini. Kriteria ini menunjuk kepada penggunaan komputer sebagai alat untuk menghasilkan gabungan beberapa elemen media tersebut.

Multimedia interaktif merupakan multimedia di mana pengguna mampu mengendalikan secara aktif elemen mana yang tampil serta kapan tampilnya elemen tersebut (Heinich et.al., 2002:150; Vaughan, 2011:1). Istilah interaktif merujuk pada kekuasaan pengendalian yang berada di tangan pengguna. Artinya, sebuah multimedia akan interaktif jika mau menampilkan menurut kehendak pengguna.

Melihat makna dan fungsi media pembelajaran sebagaimana disebutkan sebelumnya, multimedia interaktif sangat mungkin digunakan untuk memfasilitasi pembelajaran. Jika demikian, maka multimedia interaktif yang digunakan untuk memfasilitas pembelajaran dapat didefinisikan sebagai gabungan integral dari elemen-elemen teks, grafis, suara, 
animasi, dan video yang diolah secara digital melalui komputer untuk menyampaikan materi pembelajaran dari sumber belajar ke pembelajar di mana pembelajar mampu mengendalikan secara aktif elemen mana yang tampil serta kapan tampilnya elemen tersebut.

Alessi \& Trollip (2001:10) mengkategorisasikan multimedia interaktif yang digunakan untuk memfasilitasi belajar menjadi delapan metodologi, yaitu (1) tutorial, (2) hypermedia, (3) drill, (4) simulasi, (5) games, (6) perkakas dan lingkungan belajar open-ended, (7) tes, dan (8) belajar berbasis web. Kategorisasi metodologi ini bukanlah pembagian dengan sekat-sekat yang kaku. Artinya, sangat dimungkinkan suatu metodologi bercampur dengan metodologi yang lainnya. Bahkan, tidaklah mungkin satu metodologi berdiri sendiri.

\section{Simulasi}

Simulasi merupakan sebuah model dari sistem yang ada di dunia nyata (Clark \& Mayer, 2011:374). Simulasi disebut sebagai model karena ia merupakan sebuah tiruan dari sesuatu yang nyata dengan penyederhanaan.

Sehubungan dengan penggunaannya di bidang pendidikan, Alessi \& Trollip (2001:213) menyatakan bahwa simulasi edukasional merupakan sebuah model dari fenomena atau aktivitas yang dipelajari pengguna melalui interaksi dengan simulasi tersebut. Simulasi yang digunakan dalam pendidikan menuntut pembelajar untuk berinteraksi dengannya agar sebuah pembelajaran dengan menggunakan simulasi terjadi.

Simulasi mempunyai karakteristik khusus dalam hal pemodelan keadaan sebenarnya. Karakteristik tersebut adalah penyederhanaan dari keadaan sebenarnya berupa penghilangan, pengubahan, atau penambahan detil dari fiturfitur yang ada pada simulasi (Alessi \& Trollip, 2001:214).

Multimedia interaktif dalam bentuk simulasi merupakan multimedia interaktif di mana sebuah sistem atau fenomena yang ada di dunia nyata dimodelkan melalui perangkat lunak dengan penyederhanaan yang diperlukan. Pemodelan fenomena atau sistem di dunia nyata ini dilakukan dengan alasan meminimalkan biaya, meminimalkan resiko rusaknya sistem sebenarnya, meminimalkan resiko terancamnya keselamatan jiwa, atau tidak mungkinnya pembelajaran dilakukan dalam situasi sebenarnya di dunia nyata. Pembelajar belajar dengan perangkat lunak multimedia simulasi ini dengan cara berinteraksi dengan perangkat lunak tersebut.

Dipandang dari tujuan pembelajaran, simulasi terbagi atas dua kelompok besar: untuk mengajarkan tentang sesuatu (konseptual) dan untuk mengajarkan bagaimana melakukan sesuatu (operasional) (Alessi \& Trollip, 2001:214; Clark \& Mayer, 2011:376).

Dalam penelitian ini, sistem yang disimulasikan adalah software basis data Microsoft Access 2007. Berdasarkan kategorisasi dari ahli-ahli di atas, jenis simulasi software Microsoft Access 2007 yang dikaji dalam penelitian ini termasuk dalam kategori simulasi prosedural atau simulasi operasional untuk pelatihan software. Kompetensi dasar mengoperasikan software basis data bertujuan agar peserta didik mampu mengoperasikan software basis data. Berdasarkan tujuan pembelajaran ini, maka jenis simulasi yang tepat adalah simulasi prosedural, khususnya adalah simulasi untuk pelatihan aplikasi software basis data Microsoft Access 2007. Oleh karena itu, yang dimaksudkan dengan multimedia interaktif dalam penelitian ini adalah multimedia interaktif di mana software basis data Microsoft Access 2007 disimulasikan melalui perangkat lunak multimedia dengan beberapa penyederhanaan dan penambahan beberapa fitur.

\section{Evaluasi media}

Evaluasi media merupakan sebuah proses penilaian untuk mengetahui apakah media yang dikembangkan telah memenuhi standarstandar yang ditetapkan atau tidak ((Sadiman et. al., 2011:181; Alessi \& Trollip, 2001:409410). Terdapat dua macam evaluasi media, yaitu evaluasi formatif dan evaluasi sumatif (Alessi \& Trollip, 2001:553-554; Lee \& Owens, 2004:224; Sadiman et. al., 2011:182; Clark \& Mayer, 2011:461 \& 472).

Evaluasi formatif merupakan penilaian berkelanjutan yang dilakukan dari awal sampai akhir pengembangan terhadap ketercapaian standar kualitas dari media yang dikem- 
bangkan (Lee \& Owens, 2004:339; Alessi \& Trollip, 2001:413). Evaluasi formatif ini bisa dilakukan dengan tes, wawancara, atau pengisian kuosiner terhadap responden untuk menilai apakah media yang dikembangkan telah memenuhi standar kualitas. Pada model yang dikembangkan oleh Alessi \& Trollip (2001:413) yang digunakan dalam penelitian ini, evaluasi formatif mencakup tes alfa dan tes beta yang melibatkan responden ahli media, ahli materi, siswa, dan guru.

Evaluasi sumatif merupakan proses untuk menguji apakah multimedia pembelajaran yang telah dihasilkan mampu membantu siswa mencapai tujuan belajar dari proses pembelajaran yang menggunakan multimedia pembelajaran tersebut. Hal ini sejalan dengan pernyataan (Clark \& Mayer, 2011:472; Lee \& Owens, 2004:224\&341; Alessi \& Trollip, 2001:553). Evaluasi sumatif dilakukan setelah evaluasi formatif dijalankan dan setelah produk benar-benar dihasilkan serta telah direvisi dari temuan-temuan pada evaluasi formatif. Evaluasi sumatif disebut juga sebagai validasi media dan juga disebut sebagai uji keefektifan media.

\section{Kriteria kelayakan media}

Untuk menilai kualitas atau kelayakan media khususnya pada evaluasi formatif, perlu ditetapkan terlebih dahulu kriteria-kriteria kualitas atau kelayakan media. Alessi \& Trollip (2001:409) menyebutnya sebagai standar. Standar merupakan titik awal atau dasar dari sebuah proyek pengembangan yang mencerminkan kualitas yang diperjuangkan untuk dicapai oleh tim pengembang. Standar ini merupakan cerminan dari apa yang diharapkan oleh tim pengembang berkaitan dengan media yang dikembangkan.

Dengan mengadaptasi kriteria kualitas media dari Lee \& Owens (2004:118) dan Alessi \& Trollip (2001:414) maka kriteria yang digunakan untuk mengevaluasi multimedia interaktif pada penelitian ini adalah (1) lingkup pembelajaran, (2) informasi pendukung, (3) pertimbangan afektif, (4) pedagogi, (5) antarmuka, (6) navigasi, dan (7) kehandalan program.

Lingkup pembelajaran berkaitan dengan materi yang disajikan dalam multimedia pem- belajaran yang dikembangkan. Aspek-aspek yang perlu dievaluasi dari kriteria lingkup pembelajaran ini adalah kesesuaian dengan tujuan pembelajaran (Alessi \& Trollip, 2001:418), struktur materi (Alessi \& Trollip, 2001:418), keakuratan isi materi (Alessi \& Trollip, 2001:418), penggunaan bahasa (Alessi \& Trollip, 2001:419; Clark \& Mayer, 2011:182-184), dan ketersediaan glosarium (Alessi \& Trollip, 2001:421).

Informasi pendukung merupakan informasi yang terdapat pada multimedia pembelajaran tetapi tidak berhubungan secara langsung dengan materi pembelajaran. Informasi pendukung yang diharapkan tersedia pada multimedia interaktif adalah pendahuluan materi (Lee \& Owen, 2004:130; Alessi \& Trollip, 2001:421), petunjuk operasional program (Alessi \& Trollip, 2001:421), bantuan (Alessi \& Trollip, 2001:421), dan kesimpulan (Alessi \& Trollip, 2001:422).

Pertimbangan afektif menunjuk pada penyediaan program multimedia pembelajaran terhadap perubahan sikap siswa. Aspek-aspek berkaitan pertimbangan afektif ini adalah ketersediaan tantangan (Malone \& Lepper (1987) dalam Alessi \& Trollip, 2001:422), pembangkitan rasa ingin tahu (Malone \& Lepper (1987) dalam Alessi \& Trollip, 2001:422), menjaga kepercayaan diri siswa (Keller \& Suzuki (1988) dalam Alessi \& Trolllip, 2001:422), dan memuaskan keingintahuan (Keller \& Suzuki (1988) dalam Alessi \& Trolllip, 2001:422).

Pedagogi berhubungan dengan metode dan aktivitas pembelajaran yang dilakukan dengan media tersebut. Aspek yang dievaluasi berkaitan dengan kriteria pedagogi adalah kesesuaian metodologi (Alessi \& Trollip, 2001:426), interaktivitas (Alessi \& Trollip, 2001:426), kapasitas kognitif (Alessi \& Trollip, 2001:426), akomodasi terhadap belajar mandiri (Alessi \& Trollip, 2001:427), soal (Alessi \& Trollip, 2001:427), kemudahan menjawab pertanyaan soal (Alessi \& Trollip, 2001:427), dan kualitas umpan balik soal setelah dijawab (Alessi \& Trollip, 2001:428).

Antarmuka atau interface merupakan tampilan pada layar yang memfasilitasi komunikasi antara siswa dengan materi pembelajaran. Antarmuka dapat juga mencakup su- 
ara atau bentuk keluaran lainnya jika diperlukan. Aspek yang berkaitan dengan antarmuka meliputi komposisi warna (Lee \& Owens, 2004:127), proporsi tata letak tampilan di layar (Lee \& Owens, 2004:119), kualitas teks (Lee \& Owens, 2004:127; Alessi \& Trollip, 2001:423), kualitas gambar (Lee \& Owens, 2004:127; Alessi \& Trollip, 2001:424), dan kualitas klip video (Lee \& Owens, 2004:126; Alessi \& Trollip, 2001:424).

Navigasi merujuk kepada cara di mana siswa bergerak menjelajahi program multimedia dan juga orientasi -yaitu perasaan mengetahui posisi mereka pada program multimedia. Aspek yang dievaluasi berkaitan dengan navigasi mencakup ketersediaan petunjuk navigasi (Alessi \& Trollip, 2001:425) dan konsistensi navigasi (letak dan bentuk) (Alessi \& Trollip, 2001:425; Lee \& Owen, 2004:119).

Secara ideal, kehandalan program mempunyai kriteria yang sederhana: program tersebut tidak pernah gagal (Alessi \& Trollip, 2001:480). Aspek yang berkaitan dengan kehandalan program adalah penggunaan pada beberapa sistem komputer (Alessi \& Trollip, 2001:480), penggunaan secara normal (Alessi \& Trollip, 2001:480), dan penggunaan secara tidak normal (misalnya menekan sembarang tombol pada keyboard) (Alessi \& Trollip, 2001:480).

\section{Keefektifan pembelajaran dengan multimedia}

Keefektifan pembelajaran didefinisikan sebagai terwujudnya hasil pembelajaran sesuai dengan tujuan pembelajaran yang telah ditetapkan. Hal ini sejalan dengan pernyataan (Reigeluth, 1999:9; Warsita, 2008:287)

Clark \& Mayer (2011:52) berpendapat bahwa pertanyaan utama tentang keefektifan pembelajaran adalah apa yang membantu siswa belajar, dalam hal ini, "Apakah sebuah metode pembelajaran menyebabkan belajar?" Berdasarkan hal ini, Clark \& Mayer (2011:52) berpendapat bahwa metode penelitian yang tepat untuk mengetahui keefektifan pembelajaran adalah dengan mengadakan pembandingan dengan eksperimen. Dalam pembandingan dengan eksperimen tersebut, seorang peneliti membandingkan performansi tes siswa yang belajar dengan fitur pembelajaran yang diteliti dengan performansi tes siswa yang belajar tanpa fitur pembelajaran yang diteliti.

Kriteria keefektifan pembelajaran dengan multimedia interaktif dalam penelitian ini adalah jika hasil belajar dan gain kelas yang belajar dengan multimedia interaktif lebih tinggi secara signifikan daripada hasil belajar dan gain kelas yang belajar tanpa multimedia interaktif maka pembelajaran dengan multimedia interaktif dinyatakan efektif.

\section{Hasil belajar}

Hasil belajar adalah hasil yang diperoleh setelah proses pembelajaran, yaitu tingkat perkembangan mental yang lebih baik yang terwujud pada tiga kawasan yaitu: (1) kawasan kognitif, (2) kawasan afektif, dan (3) kawasan psikomotor (Dimyati \& Mudjiono, 1999:250251; Rusman, 2012:123).

Kawasan kognitif, afektif, dan psikomotor sebagai hasil belajar diformulasikan oleh Bloom dan kawan-kawan (1956:7) di mana setiap aspek mempunyai tujuan kependidikan. Taksonomi kawasan kognitif Bloom dan kawan-kawan telah dikenal dengan baik oleh pakar pendidikan dan guru di semua tingkat pendidikan di Indonesia. Taksonomi ini juga dijadikan acuan dalam merumuskan tujuan pembelajaran pada pendidikan tingkat menengah. Berdasarkan hal tersebut, dalam penelitian ini diukur hasil belajar kawasan kognitif dengan taksonomi Bloom yang telah direvisi oleh Anderson dan Krathwohl (Krathwohl, 2002:212).

Menurut Anderson dan Krathwohl (Krathwohl, 2002:215), struktur dari dimensi proses kognitif pada taksonomi yang direvisi adalah: (1) remember, yaitu memanggil kembali pengetahuan yang relevan dari memori jangka panjang; (2) understand, yaitu menentukan makna dari pesan instruksional, meliputi komunikasi lisan, tertulis, dan grafis; (3) apply, yaitu menjalankan atau menggunakan sebuah prosedur pada situasi yang ditentukan; (4) analyze, yaitu memecah materi menjadi bagian-bagian penyusunnya dan mendeteksi bagaimana bagianbagian itu saling berhubungan dan bagaimana bagian-bagian itu membentuk struktur atau maksud keseluruhan; (5) evaluate, yaitu membuat penilaian berdasarkan standar-standar atau kriteria-kriteria; (6) create, yaitu me- 
nyusun elemen-elemen secara bersama untuk membuat produk yang baru secara keseluruhan atau sebuah produk orisinal.

Dengan demikian, yang dimaksud hasil belajar kompetensi dasar Mengoperasikan software basis data dalam penelitian ini adalah hasil belajar yang merupakan perubahan tingkah laku sebagai hasil suatu kegiatan pembelajaran yang direncanakan. Perubahan tingkah laku yang dimaksud adalah perubahan kawasan kognitif yang meliputi: (1) mengingat, (2) memahami, (3) menerapkan, (4) menganalisis, (5) mengevaluasi, (6) mencipta.

\section{METODE PENELITIAN}

\section{Jenis Penelitian}

Berdasarkan permasalahan yang dikaji, maka penelitian ini termasuk dalam jenis penelitian dan pengembangan. Penelitian dan pengembangan merupakan usaha untuk merancang dan mengembangkan produk baru. Produk tersebut kemudian diujicobakan di lapangan, dievaluasi, dan diperbaiki sampai mencapai kriteria kualitas dan berdaya guna di lapangan.

\section{Model pengembangan}

Model pengembangan yang diambil untuk mengembangkan multimedia interaktif ini adalah model yang dikembangkan oleh Alessi \& Trollip (2001:408-413). Pertimbangan-pertimbangan pemilihan model ini adalah model ini merupakan model pengembangan yang dikhususkan untuk pengembangan multimedia, model ini merupakan model yang diorientasikan kepada pengembang pemula, model ini mudah dipahami dan ringkas, serta dapat diterapkan di banyak mata pelajaran.

Adapun langkah-langkah pengembangan dari model yang diciptakan Alessi \& Trollip (2001:408-413) ini adalah perencanaan, perancangan, dan pengembangan. Dalam penelitian ini, multimedia interaktif akan dikembangkan dengan model pengembangan yang diadaptasi dari model pengembangan yang diciptakan oleh Alessi \& Trollip (2001:408-413). Adaptasi model dilakukan berdasarkan pada kebutuhan pengembangan dan kemampuan pengembang.

\section{Prosedur pengembangan}

Prosedur pengembangan merupakan tahap-tahap kegiatan untuk mengembangkan produk multimedia interaktif. Tahap-tahap kegiatan ini merupakan kegiatan operasional yang nyata yang disusun secara sistematis dan berkelanjutan sehingga pada akhirnya dihasilkan produk yang layak diterapkan pada lingkungan pembelajaran.

Berdasarkan adaptasi model yang dikembangkan oleh Alessi \& Trollip (2001:409413), prosedur pengembangan multimedia interaktif dalam penelitian ini adalah sebagai berikut menentukan ruang lingkup materi, mengidentifikasi karakteristik siswa, menetapkan batasan-batasan, mengumpulkan sumber daya, membuat manual gaya, mengembangkan ide awal, analisis tugas dan konsep, membuat deskripsi program awal dalam bentuk diagram alur, mempersiapkan naskah, membuat storyboard, mempersiapkan teks, membuat elemen multimedia (teks, gambar, audio, video, kode), merakit bagian-bagian menjadi produk awal, melakukan tes alfa, merevisi berdasarkan temuan tes awal, melakukan tes beta, melakukan revisi berdasarkan temuan tes beta, melakukan pengujian keefektifan dengan desain quasi eksperimen.

\section{Uji coba produk}

Tujuan dilakukannya uji coba adalah untuk mendapatkan masukan baik dari aspek materi maupun media sehingga pada akhirnya didapatkan produk final yang benar-benar layak diterapkan pada lingkungan pembelajaran nyata. Uji coba produk multimedia interaktif ini meliputi tiga tahap, yaitu tes alfa, tes beta, dan uji keefektifan dengan quasi eksperimen.

Alessi \& Trollip (2001:548) berpendapat bahwa tes alfa merupakan tes program hasil pengembangan yang dilakukan oleh tim perancang dan pengembang. Maksud dari tes alfa adalah untuk mengidentifikasi dan mengeliminasi sebanyak mungkin masalah (Alessi \& Trollip, 2001:548). Dalam penelitian ini, tes alfa dilakukan oleh ahli media dan ahli materi dengan menjalankan produk multimedia interaktif. Kemudian, ahli media dan ahli materi menilai multimedia interaktif dari sisi lingkup pembelajaran, informasi pendukung, 
pertimbangan afektif, antarmuka, navigasi, pedagogi, dan kehandalan program.

Alessi \& Trollip (2001:550) menyatakan bahwa tes beta merupakan tes penuh untuk menguji produk akhir yang dilakukan oleh klien. Maksud tes beta adalah untuk menentukan alur pembelajaran dan menjawab pertanyaan yang muncul pada saat pengembangan materi. Dalam penelitian ini, tes beta dilakukan oleh guru dan siswa dengan menjalankan produk. Tiga siswa dipilih untuk mewakili siswa berkemampuan awal tinggi, sedang, dan rendah. Peneliti mengobservasi kegiatan peserta didik dalam menggunakan produk multimedia interaktif ini.

Uji keefektifan dilakukan secara formal dengan maksud untuk mengetahui apakah produk multimedia interaktif yang dihasilkan secara efektif membantu mencapai tujuan pembelajaran dibandingkan dengan media pembelajaran konvensional. Uji coba keefektifan mengambil tempat di SMK Negeri 1 Seyegan. Prosedur uji keefektifan mengikuti prosedur quasi eksperimen. Perancangan quasi-eksperimen digunakan dalam penelitian ini, karena peneliti tidak mungkin mengacak kelas-kelas yang telah ada di tempat penelitian. Dalam hal ini, kelompok yang akan dibandingkan mengambil dari kelas-kelas yang telah ada atau intact classes.

Desain quasi eksperimen yang digunakan adalah Non Equivalent Control Group Design. Perancangan ini melibatkan sebuah kelompok eksperimen dan sebuah kelompok kontrol. Kedua kelas tersebut diberi pretest. Rerata dan simpangan baku pretest kedua kelompok kemudian dibandingkan untuk mengetahui similaritas kedua kelompok (Isaac \& Michael, 1971:43). Setelah similaritas kedua kelompok diketahui, kelompok eksperimen diberi perlakuan dengan pembelajaran menggunakan multimedia interaktif, sedangkan kelompok kontrol menjalani pembelajaran konvensional. Setelah itu, kedua kelompok diberi posttest.

Populasi dalam quasi eksperimen ini adalah seluruh siswa kelas XI SMK N 1 Seyegan. Pada semester genap tahun pelajaran 2012/2013, kelas-kelas yang memungkinkan dikontrol aspek peristiwanya (yaitu jadwal pelajaran pada rentang waktu yang sama dan ru- angan yang sama) agar validitas internal terjaga adalah kelas-kelas pada kompetensi keahlian Teknik Kendaraan Ringan. Teknik pengambilan sampel kelas dilakukan dengan teknik simple random sampling. Dari hasil pengundian, kelas yang menjadi kelas eksperimen adalah kelas XI TKR 3 dan kelas yang menjadi kelas kontrol adalah kelas XI TKR 2.

Untuk melihat perbedaan kedua kelas, maka validitas quasi eksperimen perlu dikontrol. Kontrol validitas dimaksudkan untuk mendapatkan bahwa hasil penelitian yang diperoleh benar-benar merupakan akibat dari perlakuan yang diberikan pada kelas eksperimen maupun kelas kontrol. Beberapa hal yang dikontrol dalam validitas quasi eksperimen ini adalah aspek kematangan, aspek peristiwa dalam pembelajaran, aspek subjek penelitian, aspek mortalitas, aspek materi perlakuan, aspek tes, dan pengaruh hawthrone.

\section{Jenis data}

Jenis data yang diperoleh dari tahap uji coba ini adalah data kuantitatif yang dilengkapi dengan data kualitatif.

Data kuantitatif untuk menilai kelayakan produk diperoleh dari tes alfa dan tes beta. Selanjutnya data kuantitatif ini dikonversi ke dalam data kualitatif sehingga bisa diketahui tingkat kualitas dan kelayakan produk yang dikembangkan. Data kuantitatif hasil belajar diperoleh dari pretest dan posttest, baik dari kelas eksperimen maupun dari kelas kontrol.

\section{Instrumen dan Teknik pengumpulan data}

Instrumen yang digunakan dalam penelitian ini adalah angket untuk mengetahui kelayakan produk dan soal tes untuk mengetahui hasil belajar siswa.

Instrumen penilaian kelayakan multimedia interaktif diadaptasi dari indikatorindikator kualitas media dari Alessi \& Trollip (2001:414-431). Indikator-indikator yang dimaksud adalah lingkup pembelajaran, informasi pendukung, pertimbangan afektif, pedagogi, hubungan pengguna dengan program, navigasi, dan kehandalan program. Instrumen ini dipakai dalam tes alfa dan tes beta.

Teknik pengumpulan data yang digunakan dalam uji keefektifan ini adalah tes. Dengan 
demikian, instrumen dalam uji keefektifan adalah soal tes. Instrumen yang digunakan dalam penelitian ini berupa instrumen soal tes dalam bentuk pilihan ganda dengan empat pilihan jawaban. Untuk setiap butir soal, jawaban yang benar diberi skor 1 dan jawaban yang salah diberi skor 0 .

\section{TEKNIK ANALISIS DATA}

Analisis data dilakukan terhadap dua jenis data yaitu data penilaian kelayakan media dan data hasil belajar. Data penilaian keyalakan media dianalisis secara deskriptif. Data hasil belajar dianalisis secara deskriptif dan secara statistika inferensial.

Dalam instrumen penilaian kelayakan media, diberikan lima pilihan untuk memberikan tanggapan mengenai produk pengembangan dengan kriteria sangat baik (5), baik (4), cukup (3), kurang (2), dan sangat kurang (1). Untuk menentukan kategori dari rerata jawaban siswa dari setiap indikator (item), maka diperlukan konversi skor aktual menjadi nilai dengan pendekatan Penilaian Acuan Patokan (Sukardjo, 2005:52-53). Masukan data tersebut dianalisis secara deskriptif untuk menggambarkan kualitas tiap aspek pada unsur media dan pembelajaran.

Dalam penelitian pengembangan ini, batasan minimal nilai kelayakan produk hasil pengembangan adalah di atas 3,40 atau termasuk kategori Baik. Apabila penilaian dari ahli materi dan ahli media pada tes alfa dan penilaian guru serta siswa pada tes beta sudah memberikan hasil penilaian akhir secara keseluruhan dengan nilai minimal 3,40, maka produk pengembangan tersebut sudah dianggap layak untuk digunakan.

Analisis data yang dilakukan untuk data hasil belajar adalah uji beda dengan uji t. Penghitungan ukuran pengaruh (effect size) juga dilakukan terhadap data hasil belajar.

\section{HASIL PENELITIAN DAN PEMBAHASAN}

Produk yang dihasilkan adalah perangkat lunak multimedia interaktif yang dinamakan Simple Access 2007. Simple Access
2007 mensimulasikan Microsoft Access 2007 dengan penyederhanaan yaitu menonaktifkan menu-menu yang bukan merupakan cakupan kompetensi dasar Mengoperasikan Software Basis Data kelas XI SMK dan penambahan fitur berupa penambahan petunjuk pengoperasian per langkah dalam bahasa Indonesia serta penambahan umpan balik dalam bahasa Indonesia untuk merespon langkah yang dilakukan siswa.

Produk yang dikembangkan dinilai kualitas kelayakannya melalui tes alfa dan tes beta. Tes alfa melibatkan ahli media dan materi serta dilakukan dengan cara menjalankan produk multimedia hasil pengembangan.

Data kelayakan media yang diperoleh dari ahli media beserta analisisnya adalah: (1) indikator informasi pendukung mendapatkan nilai rata-rata 5 dan termasuk ke dalam kategori sangat baik, (2) indikator hubungan pengguna dengan program (antarmuka) mendapatkan nilai rata-rata 4,71 dan termasuk ke dalam kategori sangat baik, (3) indikator navigasi mendapatkan nilai rata-rata 4 dan termasuk ke dalam kategori baik, (4) indikator pedagogi mendapatkan nilai rata-rata 4,33 dan termasuk ke dalam kategori sangat baik, (5) indikator kehandalan program mendapatkan nilai rata-rata 4 dan termasuk ke dalam kategori baik. Ratarata penilaian ahli media terhadap produk yang dikembangkan ini adalah 4,41 dan termasuk ke dalam kategori sangat baik. Ahli media juga menyarankan perubahan tata letak tombol ke materi, penambahan menu sub materi, dan keterangan tentang pengembang yang lebih lengkap.

Data kelayakan media yang diperoleh dari ahli materi beserta analisisnya adalah (1) indikator lingkup pembelajaran mendapatkan nilai rata-rata 4,2 dan termasuk ke dalam kategori baik, (2) indikator informasi pendukung mendapatkan nilai rata-rata 4 dan termasuk ke dalam kategori baik, (3) indikator pertimbangan afektif mendapatkan nilai rata-rata 4,25 dan termasuk ke dalam kategori sangat baik, (4) indikator pedagogi mendapatkan nilai ratarata 4,5 dan termasuk ke dalam kategori sangat baik. Rata-rata penilaian ahli materi terhadap produk yang dikembangkan ini adalah 4,24 dan termasuk ke dalam kategori sangat baik. 
Berdasarkan validasi ahli materi pada tes alfa, produk yang dikembangkan sudah layak diujicobakan tanpa revisi. Saran yang diberikan ahli materi adalah tombol "lanjutkan" pada halaman judul terlalu kecil dan sebaiknya dibesarkan agar lebih terlihat.

Tes beta melibatkan dua orang guru yang mengajarkan mata pelajaran yang sama (KKPI) dan enam peserta didik. Keenam peserta didik ini terdiri dari dua orang berkemampuan rendah, dua orang berkemampuan sedang, dan dua orang berkemampuan tinggi. Tes beta ini dilakukan untuk menilai aspek media dan aspek materi dengan cara menjalankan produk.

Pada aspek materi, data hasil penilaian guru beserta analisisnya adalah: (1) indikator lingkup pembelajaran mendapatkan nilai rata-rata 4,6 dan termasuk ke dalam kategori sangat baik, (2) indikator informasi pendukung mendapatkan nilai rata-rata 4,38 dan termasuk ke dalam kategori sangat baik, (3) indikator pertimbangan afektif mendapatkan nilai ratarata 4,5 dan termasuk ke dalam kategori sangat baik, (4) indikator pedagogi mendapatkan nilai rata-rata 4,38 dan termasuk ke dalam kategori sangat baik. Pada aspek media, data hasil penilaian guru beserta analisisnya adalah: (1) indikator informasi pendukung mendapatkan nilai rata-rata 4,5 dan termasuk ke dalam kategori sangat baik, (2) indikator hubungan pengguna dengan program (antarmuka) mendapatkan nilai rata-rata 4,43 dan termasuk ke dalam kategori sangat baik, (3) indikator navigasi mendapatkan nilai rata-rata 4,5 dan termasuk ke dalam kategori sangat baik, (4) indikator pedagogi mendapatkan nilai rata-rata 4,28 dan termasuk ke dalam kategori sangat baik, (5) indikator kehandalan program mendapatkan nilai rata-rata 4,5 dan termasuk ke dalam kategori sangat baik. Berdasarkan data penilaian dua guru dalam tes beta tersebut diperoleh hasil bahwa rata-rata penilaian terhadap produk yang dikembangkan adalah 4,45 dan termasuk ke dalam kategori sangat baik. Dalam penilaian tersebut, kedua guru mempunyai kesimpulan bahwa produk yang dikembangkan sudah dapat diujicobakan.

Dari penilaian siswa, didapatkan data aspek materi beserta analisisnya, yaitu: (1) indikator lingkup pembelajaran mendapatkan nilai rata-rata 4,1 dan termasuk ke dalam kategori baik, (2) indikator informasi pendukung mendapatkan nilai rata-rata 4,29 dan termasuk ke dalam kategori sangat baik, (3) indikator pertimbangan afektif mendapatkan nilai ratarata 4,04 dan termasuk ke dalam kategori baik, (4) indikator pedagogi mendapatkan nilai ratarata 4,04 dan termasuk ke dalam kategori baik. Pada aspek media, data hasil penilaian siswa beserta analisisnya adalah: (1) indikator informasi pendukung mendapatkan nilai rata-rata 4,33 dan termasuk ke dalam kategori sangat baik, (2) indikator hubungan pengguna dengan program (antarmuka) mendapatkan nilai ratarata 4,24 dan termasuk ke dalam kategori sangat baik, (3) indikator navigasi mendapatkan nilai rata-rata 3,83 dan termasuk ke dalam kategori baik, (4) indikator pedagogi mendapatkan nilai rata-rata 3,93 dan termasuk ke dalam kategori baik, dan (5) indikator kehandalan program mendapatkan nilai rata-rata 4,33 dan termasuk ke dalam kategori sangat baik. Berdasarkan data penilaian siswa dalam tes beta tersebut diperoleh hasil bahwa rata-rata penilaian terhadap produk yang dikembangkan adalah 4,13 dan termasuk ke dalam kategori baik. Berdasarkan hasil tes beta oleh guru dan siswa tersebut, produk siap diuji keefektifannya dalam pembelajaran.

Langkah pertama dalam uji keefektifan adalah menguji kemampuan awal subjek penelitian dengan melakukan pretest. Setelah perlakuan diberikan, dilakukan pengujian hasil belajar dengan post test. Sebelum uji beda kemampuan awal dan hasil belajar dilakukan, terlebih dahulu dilakukan uji prasyarat untuk mengetahui normalitas dan homogenitas data. Berikut ini adalah ringkasan hasil uji prasyarat data sebelum dan setelah diberi perlakuan, yang menunjukkan bahwa data memenuhi prasyarat analisis.

Tabel 2. Ringkasan hasil uji prasyarat data sebelum dan sesudah perlakuan

\begin{tabular}{ll}
\hline Data & Keputusan \\
Pretest & Kemampuan awal sama \\
\hline Prasyarat analisis & \\
\hline pretest & Normal dan homogen \\
postest & Normal dan homogen \\
\hline
\end{tabular}


Analisis perbedaan hasil belajar dan gain dilakukan dengan uji-t melalui bantuan software SPSS 19. Berikut ini adalah rangkuman hasil uii $t$ terhadap data hasil belajar dan gain.

Tabel 3. Rangkuman Hasil Uji T Data Hasil Belajar dan Gain

\begin{tabular}{lll}
\hline \multicolumn{1}{c}{ Data } & \multicolumn{1}{c}{$\begin{array}{c}\text { Sig } \\
\text { (2-tailed) }\end{array}$} & Keputusan Uji \\
\hline Hasil Belajar & 0,00 & Terdapat perbedaan \\
Gain & 0,00 & Terdapat perbedaan \\
\hline
\end{tabular}

Hipotesis yang akan diuji terhadap data hasil belajar adalah $\mathrm{H}_{\mathrm{o}}$ : tidak terdapat perbedaan hasil belajar yang signifikan antara kelas eksperimen dan kelas kontrol dan $\mathrm{H}_{\mathrm{a}}$ : terdapat perbedaan hasil belajar yang signifikan antara kelas eksperimen dan kelas kontrol. Hasil analisis menunjukkan bahwa nilai sig. (2-tailed) sebesar 0,000 , hal ini menunjukkan bahwa nilai signifikansi pengujian data hasil belajar kurang dari 0,05. Dengan demikian dapat disimpulkan bahwa $\mathrm{H}_{\mathrm{o}}$ ditolak dan $\mathrm{H}_{\mathrm{a}}$ diterima. Hal ini berarti terdapat perbedaan hasil belajar yang signifikan antara kelas eksperimen dan kelas kontrol.

Hipotesis yang akan diuji terhadap data gain adalah $\mathrm{H}_{\mathrm{o}}$ : tidak terdapat perbedaan gain yang signifikan antara kelas eksperimen dan kelas kontrol dan $\mathrm{H}_{\mathrm{a}}$ : terdapat perbedaan gain yang signifikan antara kelas eksperimen dan kelas kontrol. Hasil analisis menunjukkan bahwa nilai sig. (2-tailed) sebesar 0,000, hal ini menunjukkan bahwa nilai signifikansi pengujian data gain kurang dari 0,05. Dengan demikian dapat disimpulkan bahwa $\mathrm{H}_{\mathrm{o}}$ ditolak dan $\mathrm{H}_{\mathrm{a}}$ diterima. Hal ini berarti terdapat perbedaan gain yang signifikan antara kelas eksperimen dan kelas kontrol.

Penghitungan ukuran pengaruh dilakukan dengan cara mengurangi rata-rata nilai posttest kelompok eksperimen dengan rata-rata nilai posttest kelompok kontrol kemudian dibagi dengan simpangan baku nilai posttest hasil belajar kelompok kontrol. Dari data di atas, didapatkan nilai ukuran pengaruh $=(79,51$ $-65,63) / 7,88=1,76$. Berdasarkan interpretasi ukuran pengaruh yang disarankan Cohen (Muijs, 2004:139), maka ukuran pengaruh dengan nilai 1,76 merupakan pengaruh yang kuat.
Melihat ukuran pengaruh yang positif, terlihat pula bahwa rata-rata posttest kelas eksperimen adalah lebih tinggi daripada rata-rata posttest kelas kontrol. Dengan demikian, di samping secara statistik signifikan, perbedaan rata-rata posttest sebesar 13,88 antara kelas eksperimen dan kelas kontrol secara praktis adalah signifikan.

Data hasil belajar kelas eksperimen dan kelas kontrol menunjukkan bahwa rata-rata hasil belajar Kompetensi Dasar Mengoperasikan Software Basis Data kelas eksperimen adalah lebih tinggi dibandingkan dengan rata-rata hasil belajar kelas kontrol $(79,51>65,63)$. Rata-rata pencapaian hasil belajar (gain) kelas eksperimen juga lebih tinggi dibandingkan dengan rata-rata pencapaian hasil belajar (gain) kelas kontrol $(28,15>16,09)$. Berdasarkan analisis data hasil belajar serta analisis data gain kelas eksperimen dan kelas kontrol, maka diketahui perbedaan ini adalah signifikan secara statistik. Dengan demikian dapat disimpulkan bahwa pembelajaran dengan multimedia interaktif adalah lebih efektif dibandingkan dengan pembelajaran tanpa multimedia interaktif.

\section{SIMPULAN DAN SARAN}

\section{Simpulan}

Berdasarkan hasil penelitian dan pengembangan yang telah dilakukan, dapat diambil kesimpulan sebagai berikut :

1. Produk pengembangan yang dihasilkan merupakan multimedia interaktif Simple Access 2007. Produk tersebut menyajikan materi pembelajaran Keterampilan Komputer dan Pengelolaan Informasi Kompetensi Dasar Mengoperasikan Software Basis Data untuk kelas XI SMK semua kompetensi keahlian. Simple Access 2007 mensimulasikan Microsoft Access 2007 dengan penyederhanaan yaitu menonaktifkan menu-menu yang bukan merupakan cakupan kompetensi dasar Mengoperasikan Software Basis Data kelas XI SMK dan penambahan fitur berupa penambahan petunjuk pengoperasikan per langkah dalam bahasa Indonesia serta penambahan umpan balik dalam bahasa Indonesia untuk merespon langkah yang dilakukan siswa. 
2. Produk pengembangan multimedia interaktif Simple Access 2007 layak sebagai media pembelajaran ditinjau dari lingkup pembelajaran, informasi pendukung, pertimbangan afektif, pedagogi, hubungan pengguna dengan program, navigasi, dan kehandalan program berdasarkan validasi ahli media dan ahli materi serta penilaian guru dan peserta didik.

3. Pembelajaran Kompetensi Dasar Mengoperasikan Software Basis Data dengan multimedia interaktif Simple Access 2007 lebih efektif dibandingkan pembelajaran Kompetensi Dasar Mengoperasikan Software Basis Data tanpa multimedia interaktif Simple Access 2007. Hal ini terbukti dengan adanya perbedaan hasil belajar Kompetensi Dasar Mengoperasikan Software Basis Data dan gain yang signifikan antara siswa yang belajar dengan multimedia interaktif Simple Access 2007 dengan siswa yang belajar tanpa multimedia interaktif tersebut. Hasil belajar Kompetensi Dasar Mengoperasikan Software Basis Data siswa yang belajar dengan multimedia interaktif Simple Access 2007 lebih tinggi dibandingkan dengan siswa yang belajar tanpa multimedia interaktif tersebut. Gain Kompetensi Dasar Mengoperasikan Software Basis Data siswa yang belajar dengan multimedia interaktif Simple Access 2007 juga lebih tinggi dibandingkan dengan gain siswa yang belajar tanpa multimedia interaktif tersebut.

\section{Saran}

Berdasarkan kesimpulan hasil penelitian, maka implikasi hasil penelitian tersebut adalah sebagai berikut :

1. Produk pengembangan multimedia interaktif dapat digunakan sebagai media dalam kegiatan pembelajaran mata pelajaran Keterampilan Komputer dan Pengelolaan Informasi Kompetensi Dasar Mengoperasikan Software Basis Data.

2. Jenis simulasi pengoperasian software dapat digunakan tidak hanya pada kompetensi mengoperasikan software basis data semata, namun juga pada kompetensi mengoperasikan software-software lain- nya. Jenis simulasi pengoperasian software juga tidak terbatas untuk diterapkan pada mata pelajaran Keterampilan Komputer dan Pengelolaan Informasi, namun juga pada mata pelajaran lainnya sepanjang berbentuk kompetensi mengoperasikan software.

3. Pengembangan media pembelajaran perlu memperhatikan aspek media dan aspek materi. Media pembelajaran yang dikembangkan perlu divalidasi oleh ahli media, ahli materi dan diujicobakan kepada penggunanya, yaitu siswa dan guru.

Berdasarkan kesimpulan dan implikasi penelitian diatas, berikut adalah beberapa saran untuk meningkatkan hasil belajar siswa, antara lain :

1. Sekolah dan guru dapat memanfaatkan multimedia interaktif Simple Access 2007 sebagai salah satu media pembelajaran terutama untuk kegiatan belajar mandiri mata pelajaran KKPI kompetensi dasar Mengoperasikan Software Basis Data.

2. Pembelajaran dengan memanfaatkan multimedia interaktif perlu didukung dengan fasilitas yang memadai seperti tersedianya headset untuk mendengarkan audio multimedia pembelajaran secara pribadi, software driver untuk kelancaran berjalannya multimedia pembelajaran, serta softwaresoftware pendukung lainnya.

3. Produk multimedia interaktif Simple Access 2007 dapat dikembangkan lebih lanjut dengan menyempurnakan simulasi $\mathrm{Mi}$ crosoft Access 2007 lebih utuh. Pengembangan produk ini juga dapat dilakukan dengan menambah percabangan kemungkinan pembuatan objek-objek basis data pada latihan simulasi misalnya pada pemilihan field yang akan ditampilkan pada report atau form, dan pemilihan tata letak form atau report.

\section{DAFTAR PUSTAKA}

Alessi, S.M., \& Trollip, S.R. (2001). Multimedia for learning: methods and develop-

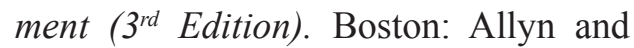
Bacon. 
Bloom, B (ed). (1956). Taxonomy of educational objectives: the classification of educational goals. Handbook 1 cognitive domain. New York: David McKay Company.

Clark, R.C., \& Mayer, R.E. (2011). E-learning and the science of instruction: proven guidelines for consumers and designers of multimedia learning ( $3^{\text {rd }}$ Edition). San Fransico: Pfeiffer.

Dimyati \& Mudjiono. (2002). Belajar dan pembelajaran. Jakarta: Rineka Cipta.

Heinich, R., Molenda, M., Russel, J.D., et al. (1996). Instructional media and technologies for learning (5 $5^{\text {th }}$ Edition). New Jersey: Prentice Hall.

Heinich, R., Molenda, M., Russel, J.D., et al. (2002). Instructional media and technologies for learning ( $7^{\text {th }}$ Edition). New Jersey: Prentice Hall.

Ivers, K.S.,\& Barron, A.E., (2002). Multimedia projects in education: designing, producing, and assessing. WestPort: Libraries Unlimited.

Krathwohl, D.R. (Autumn 2002). A revision of Bloom's taxonomy: an overview. Theory Into Practice, 41,212-218.

Lee, W.W., \& Owens, D.L.(2004). Multimediabased instructional design: computerbased training, web-based training, distance broadcast training, performancebased solutions. San Fransisco: Pfeiffer.
Reigeluth, C.M. (1999). What is instructionaldesign theory and how is it changing. Dalam Reigeluth, C.M. (Eds), Instructional-design theories and models: A new paradigm of instructional theory (Volume II)(pp 1-28). New Jersey: Lawrence Erlbaum Associates, Inc. Publishers.

Sadiman, A.S., Rahardjo, R., Haryono, A., et. al. (2011). Media pendidikan: pengertian, pengembangan, dan pemanfaatannya. Jakarta: Rajawali Press.

Sidhu, M. S. (2010). Technology-assisted problem solving for engineering education: interactive multimedia applications. New York: Engineering Science Reference.

Smaldino, E.S., Russel, J.D., Heinich, R., et al. (2004). Instructional media and technologies for learning ( $8^{\text {th }}$ Edition). New Jersey: Pearson Merril Prentice Hall.

Sukardjo. (2005). Modul perkuliahan evaluasi pembelajaran. Yogyakarta: Program Pascasarjana Universitas Yogyakarta.

Vaughan, T. (2011). Multimedia: making it work ( (th $^{\text {th }}$ dition). New York: McGrawHill.

Winataputra, U. S., et al. (2008). Teori belajar dan pembelajaran. Jakarta: Penerbit Universitas Terbuka 